\title{
Yaşlılarda Farmakolojik Olmayan Uygulamalar ve Etkisinin İncelenmesine Yönelik Türkiye'deki Mevcut Tezlerin Değerlendirilmesi $\infty$
}

\author{
Kamuran ÖZDíL ${ }^{1}$, Gamze MUZ², Gülhan KÜçÜK ÖZTÜRK ${ }^{3}$
}

\section{öz}

Amaç: Bu çalışma, yaşlılarda kullanılan farmakolojik olmayan uygulamalar ve bu uygulamaların hangi semptomlar üzerinde kullanıldığını belirlemek amacıyla yapılmışır.

Gereç ve Yöntem: Araştırma tanımlayııı tipte yapılmıştır. Veri toplama aşamasında; Yükseköğretim Kurulu Ulusal Tez Merkezi Veri Tabanı'na "geriatri", "müzik", "refleksoloji”, "akupres", "masaj", "aromaterapi" "tamamlayıcı", "alternatif tedaviler" anahtar kelimeleri yazılarak belirlenen tezler araştırma kapsamına alınmıştır. Türkiye'de yaşlılarda farmakolojik olmayan uygulamalara ve uygulanan semptomların etkisine yönelik toplam 33 teze ulaşılmıştır. Yedi tezin tam metnine ulaşılamadığı için kapsam dışı bırakılmış ve toplam 26 tez değerlendirilmiştir.

Bulgular: Bu çalışmada incelenen tezlerin çoğunluğu hemşirelik alanında yürütülmüştür. Farmakolojik olmayan yöntemler ile ilgili tezlerin; \%53.8'i doktora, \%46.2'si yüksek lisans tezidir. Farmakolojik olmayan uygulamaların yaşlılarda; anksiyete, uyku ve yaşam kalitesi, ağrı, yalnızlık, yorgunluk, depresyon ve konstipasyon üzerine olumlu etkisinin olduğu belirlenmiştir.

Sonuç: Yaşıllara uygulanan farmakolojik olmayan yöntemlerin birçok semptomun yönetiminde etkili olduğu görülmektedir. Sonuç olarak, alana daha fazla kanıt sağlayacak multidisipliner ve randomize kontrollü çalışmaların yapılması önerilmektedir. Anahtar kelimeler: Bütüncül sağlık, hemşirelik, tamamlayıcı tıp, tezler, yaşlı.

\begin{abstract}
An Evaluation of Dissertations/Theses in Turkey on NonPharmacological Practices and Effects in the Elderly

Aim: This study was conducted to determine the nonpharmacological practices used in the elderly and on which symptoms these practices were used.

Material and Methods: This research was carried out as a descriptive study. During data collection; theses determined by using keywords "geriatrics", "music", "reflexology", "acupressure", "massage", "aromatherapy" "complementary", "alternative treatments" on the National Thesis Center of the Higher Education Institution database were included in the study. In Turkey, a total of 33 theses on non-pharmacological practices and effects of symptoms in the elderly were reached. The full text of seven theses could not be reached and was excluded. A total of 26 theses were evaluated in the study. Since the full text of the seven theses could not be reached, it was excluded and a total of 26 theses were evaluated.

Results: Most of the theses examined in this study were conducted in the field of nursing. $53.8 \%$ of the non-pharmacological theses were PhD theses and $46.2 \%$ of them were master's theses. It was determined that non-pharmacological practices had positive effects on anxiety, sleep and quality of life, pain, loneliness, fatigue, depression and constipation in the elderly.

Conclusion: Non-pharmacological practices applied to the elderly seem to be effective in management of many symptoms. In conclusion, multidisciplinary and randomized controlled trials are recommended to provide more evidence to the field.

Keywords: Complementary medicine, elderly, holistic health, nursing, theses.
\end{abstract}

1̇̈ğr.Gör.Dr., Nevşehir Hacı Bektaş Veli Üniversitesi Sağlık Hizmetleri Meslek Yüksekokulu, Nevşehir, Türkiye, E-mail: kamuranozdil2008@gmail.com, Tel: 0384 228 10 00, ORCID: 0000-0003-0852-7854

${ }^{2}$ Dr.Öğr.Üyesi, Nevşehir Hacı Bektaş Veli Üniversitesi Semra ve Vefa Küçük Sağlık Bilimleri Fakültesi, Nevşehir, Türkiye, E-mail: gamzeucakan@gmail.com, Tel: 0384215 2380 / 23027, ORCID: 0000-0002-1452-9250

${ }^{3}$ Araş.Gör., Nevşehir Hacı Bektaş Veli Üniversitesi Semra ve Vefa Küçük Sağlık Bilimleri Fakültesi, Nevşehir, Türkiye, E-mail: glhnkck@hotmail.com, Tel: 038421523 80/23024, ORCID: 0000-0002-9220-6051

Geliş Tarihi: 23 Ağustos 2019, Kabul Tarihi: 14 Mayıs 2020

*Bu çalışma, 22-23 Mart 2017 tarihinde İzmir'de gerçekleştirilen 1. Uluslararası 10. Ulusal İzmir ileri Yaş Sempozyumu'nda poster bildiri olarak sunulmuştur.

Atıf/Citation: Özdil K, Muz G, Küçük Öztürk G. Yaşlılarda Farmakolojik Olmayan Uygulamalar ve Etkisinin İncelenmesine Yönelik Türkiye'deki Mevcut Tezlerin Değerlendirilmesi. Hacettepe Üniversitesi Hemşirelik Fakültesi Dergisi 2020; 7(3): 196-205. DOI: 10.31125/hunhemsire.834007 


\section{Giriş}

Hastalıkların tedavisinde farmakolojik olmayan yöntemler antik çağdan günümüze kadar insanoğlu tarafından kullanılmıştır. Toplumların kültürel yapısının ise bu yöntemleri kullanmada önemli bir bileşen olduğu belirtilmektedir ${ }^{1}$. Dünya Sağlık Örgütü 170 üye devletin $\% 88^{\prime}$ inin geleneksel ve tamamlayıcı yöntem (TAT) kullandığını bildirmiştir ${ }^{2}$. Birçok farklı kültürü içinde barındıran Amerika Birleşik Devletleri (ABD)'nde tamamlayıcı uygulamaların yaygın olduğu bildirilmiştir ${ }^{3}$. Çok geniş bir coğrafyadan etkilenen Türk kültüründe de hasta bakımında geleneksel uygulamalar bölgeler arası farklılık göstererek kullanıldığı belirtilmektedir ${ }^{4}$. Gök ve arkadaşlarının bildirdiğine göre Türkiye'de de TAT kullanımının arttığı ve bu oranın \%22 ile \%98.3 arasında değişim gösterdiği belirtilmektedir ${ }^{5}$. Son yıllarda yaşam süresinin artmasına bağlı olarak yaşlı nüfus sayısı da artmıştır. Bunun sonucu olarak birden fazla kronik hastalığa sahip olma, çoklu ilaç kullanımı, tedaviden istenilen düzeyde etki görememe, sağlık personelinin her hastaya yeterli vakit ayıramaması gibi nedenlerden dolayı TAT kullanımının da giderek arttığı bildirilmektedir6-8. Literatür incelendiğinde özellikle yaşı bireylerde TAT kullanım oranlarının \%54 ile \%98 arasında değişim göstermektedir ${ }^{9-12}$. Geleneksel tıbbın yaygın olarak kullanıldığı Çin'de yaşılıarda osteoartitde ağrı ile baş edebilmek için geleneksel yöntemlerin yüksek oranlarda kullanıldığı belirtilmektedir ${ }^{13}$.

Literatürde farmakolojik olmayan yöntemler arasında müzik terapisi, hipnoz, masaj, refleksoloji, aroma terapi, reiki, bitkisel ürünler gibi yöntemler belirtilmektedir ${ }^{14}$. Bu yöntemlerin yaşlı nüfusta önemli oranlarda tıbbi tedaviyle ya da tıbbi tedaviden bağımsız bir şekilde kullanıldığı belirtilmektedir. Farmakolojik olmayan yöntemler birçok yönden yararlı olmalarına rağmen gençlerle karşılaştırıldığında yaşılarda ilaç-ilaç, ilaç besin etkileşimleri gibi bir dizi soruna neden olabilmekte ve bu aşamada yaşııların bilgi gereksinimlerinin önemli olduğu vurgulanmaktadır ${ }^{15,16}$. Yaşlılara bütüncül bakım sunulabilmesinde ve bu yöntemlerin bilinçsizce kullanımının önlenmesinde sağlık profesyonellerinin ve özellikle hemşirelerin önemli görevleri bulunmaktadır. Hemşireler bu uygulamaların yaşılır üzerindeki duygusal ve psikolojik etkilerini göz ardı etmemelidir. Yaşıların farmakolojik olmayan uygulamalar konusundaki bilgilerini artırmalı, yaşlılarla güvenli ve açık iletişim kurarak bütüncül bakım sunmalıdır ${ }^{17}$. Dünyada ve Türkiye'de yaşlılara yönelik yapılan farmakolojik olmayan uygulamalara ilişkin çalışmaların oldukça fazla olduğu söylenebilir3,12,13. Konu ile ilgili bilimsel çalışmalara ait mevcut durumun ortaya konmasının gelecekte yapılacak araştırmalardaki önceliklerin belirlenmesi için literatüre aynı zamanda hemşirelik bakım uygulamalarına katkı sağlayacağı düşünülmektedir.

\section{Araştırmanın Amacı}

Türkiye'de yaşılıara yönelik yapılan farmakolojik olmayan uygulamalar ve bu uygulamaların semptomlara etkilerinin incelenmesine ilişkin mevcut tezlerin incelenmesidir.

\section{GEREÇ ve YÖNTEM}

\section{Araştırmanın Türü}

Bu araştırma yaşlılara yönelik yapılan farmakolojik olmayan uygulamalara ilişkin literatür incelenerek derleme niteliğinde hazırlanmıştır.

\section{Verilerin Toplanması}

\section{Araştırmaya Dahil Edilme Ölçütleri}

Türkiye'de, yaşlılara yönelik yapılan farmakolojik olmayan uygulamalar ve bu uygulamaların etkilerinin incelenmesine yönelik, yarı deneysel ve deneysel, Yüksek Öğrenim Kurumu (YÖK) Ulusal Tez Merkezi veri tabanında tam metnine ulaşılabilen tezler incelemeye dâhil edilmiştir. Tarama yapılırken yıl sınırlaması yapılmamıştır.

\section{Araştırmaya Dahil Edilmeme Ölçütleri}

Taramanın yapıldığı tarihte (Eylül - Ekim 2018) YÖK Ulusal Tez Merkezi veri tabanından tam metnine ulaşılamayan tezler incelemeye dâhil edilmemiştir.

\section{Veri Kaynakları ve Taramalar/Tarama Stratejisi}

Türkiye'de yaşlılara yönelik yapılan farmakolojik olmayan uygulamalar ve uygulamaların semptomlara etkilerine yönelik mevcut tezlere ulaşmak için YÖK Ulusal Tez Merkezi veri tabanı taranmıştır. Taramalar, Eylül - Ekim 2018 tarihleri arasında; "geriatri, terapi, müzik terapisi, müzikoterapi, refleksoloji, akupres, masaj, aromaterapi, tamamlayıc tedaviler, alternatif tedaviler, tamamlayıcı ve alternatif tedaviler", ışık tedavisi, uğraşı aktivitesi, anımsama terapisi anahtar sözcükleri kullanılarak online yapılmıştır. Anahtar sözcüklerin belirlenmesinde ABD Ulusal Tamamlayıcı ve Bütünleştirici Sağlık Merkezi (National Center on Complementary and Integrative Health-NCCIH) TamamlayıcI Alternatif Tedaviler (TAT) uygulamaları sınıflandırılması referans alınmıştır $(\mathrm{NCClH})^{18}$. Yapılan inceleme sonucunda Türkiye'de yaşlılara yönelik yapılan farmakolojik olmayan uygulamalar ve uygulamaların semptomlara etkisine yönelik toplam 33 teze ulaşılmıştır. Çalışmaların $15^{\prime} i$ yüksek lisans tez çalışması olup, $18^{\prime} \mathrm{i}$ doktora tez çalışmasıdır. Yüksek lisans/doktora tez çalışmalarından 7 tezin tam metnine ulaşılamadığı için kapsam dışı bırakılmış olup toplam 26 tez ( $n$ : Yüksek Lisans:12, Doktora:14) değerlendirilmiştir (Şekil 1). 


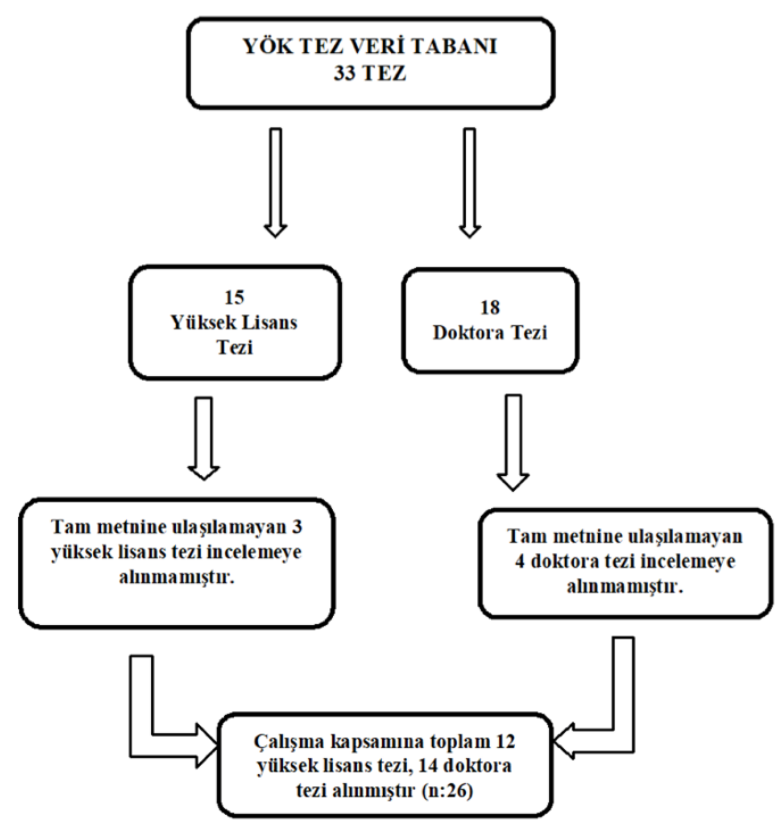

Şekil 1. Veri Tarama Akış Şeması

\section{Veri Toplama Araçları}

Çalışmaya alınan araştırmalar konu, kapsam ve yaşlılara yönelik uygulamaların şekli açısından değerlendirilmiştir. Verilerin toplanmasında, araştırmacılar tarafından literatür incelenerek geliştirilen 11 sorudan oluşan veri özeti formu kullanılmıştır ${ }^{19,20}$. Inceleme listesinde tezin yapıldığı anabilim dalı, tezin türü, tezin yılı, çalışılan bireyin cinsiyeti, çalışılan bireyin özelliği (sağlıklı / hasta birey ya da hastalık türü), çalışmanın türü, çalışmanın amacı, kullanılan farmakolojik olmayan yöntem, incelenen semptomlar, kullanılan ölçekler ve kullanılan yöntemin etkisi (olumlu/olumsuz) yer almaktadır.

\section{Verilerin Analizi}

Verilerin değerlendirilmesi üç ay sürmüş, bir tezin incelenmesi ise araştırmacının ortalama 60 dakikasını almıştır. Verilerin analizinde, tezler değerlendirme listesindeki 11 soruya göre araştırmacılar tarafından incelenmiştir. Yapılan inceleme sonucunda toplam 26 teze ait bulgular 11 soru kapsamında sayı ve yüzde verilerek sunulmuştur.

\section{Araştırmanın Etik Boyutu}

Bu çalışmada, Yüksek Öğretim Kurumu ulusal tez merkezinde erişim izni olan 33 tez kullanılmış, erişim izni olmayan 7 tezin tam metnine ulaşılamadığı için çalışmaya dahil edilmemiş ve toplam 26 tez değerlendirilmiştir. Bu doğrultuda etik kurul izni alınmasına gerek duyulmamıştır.

\section{BULGULAR}

Çalışmada incelenen tezlerin yarıdan fazlası ( $n=19)$ hemşirelik alanında yürütülmüştür. Tezlerin; $\% 26.9^{\prime} u$ i̧̧ hastalıkları hemşireliği, \%19.2'si hemşirelik esasları, \%11.5'i hemşirelik ana bilim dalı, \%7.7'si halk sağlığı hemşireliği, \%3.8'i psikiyatri hemşireliği, \%3.8'i cerrahi hastalıkları hemşireliği alanında yürütülmüştür. Diğer alanlarda yürütülen tezler ( $n=7)$ ise; halk sağlığı ana bilim dalı, Türk musikisi ana sanat dalı, radyo televizyon sinema ana bilim dalı, klinik psikoloji ana bilim dalı, psikoloji ana bilim dalı, iş ve uğraşı tedavisi programı, geriatrik fizyoterapi alanlarında yürütülmüştür (Tablo 1).

Tablo 1. Yaşlılarda Farmakolojik Olmayan Uygulamalara Yönelik Türkiye'deki Mevcut Tezlerin Özellikleri ( $n=26)$

\begin{tabular}{|c|c|c|}
\hline & & \\
\hline & $\mathbf{n}$ & $\%$ \\
\hline \multicolumn{3}{|l|}{ Tezin Türü } \\
\hline Doktora & 14 & 53.8 \\
\hline Yüksek Lisans Tezi & 12 & 46.2 \\
\hline \multicolumn{3}{|l|}{ Tezin Yapıldığı Anabilim dalı (ABD) } \\
\hline Hemşirelik ABD & 3 & 11.5 \\
\hline Hemşirelik Esasları ABD & 5 & 19.2 \\
\hline İç Hastalıkları Hemşireliği ABD & 7 & 26.9 \\
\hline Cerrahi Hastalıkları Hemşireliği ABD & 1 & 3.8 \\
\hline Psikiyatri Hemşireliği ABD & 1 & 3.8 \\
\hline Halk Sağlığı Hemşireliği ABD & 2 & 7.7 \\
\hline Halk Sağlığı ABD & 1 & 3.8 \\
\hline Türk Musikisi Ana Sanat Dalı & 1 & 3.8 \\
\hline $\begin{array}{l}\text { Radyo Televizyon Sinema Anabilim } \\
\text { Dalı }\end{array}$ & 1 & 3.8 \\
\hline Klinik Psikoloji ABD & 1 & 3.8 \\
\hline Psikoloji ABD & 1 & 3.8 \\
\hline İş ve Uğraşı Tedavisi Programı & 1 & 3.8 \\
\hline Geriatrik Fizyoterapi & 1 & 3.8 \\
\hline \multicolumn{3}{|l|}{ Araştırmanın deseni } \\
\hline Deneysel & 18 & 69.2 \\
\hline Yarı Deneysel & 8 & 30.8 \\
\hline \multicolumn{3}{|l|}{$\begin{array}{l}\text { Örneklem Grubunun Yaşadığı Yer } \\
\text { Özellikleri }\end{array}$} \\
\hline Sürekli Kurumsal Bakım Hizmeti alan* & 22 & 84.6 \\
\hline Hastanede Tedavi gören** & 4 & 15.4 \\
\hline Toplam & 26 & 100.0 \\
\hline
\end{tabular}

*Kurumsal Bakım: huzurevi, bakımevi, dinlenme evi, huzurevi ve rehabilitasyon merkezi

Incelenen tezlerin \%53.8'inin doktora, \%46.2'sinin yüksek lisans tezi olduğu ve \%69.2'sinde deneysel, \%30.8'inde yarı deneysel araştırma yöntemi kullanıldığı saptanmıştır. Örneklem grubunun özellikleri incelendiğinde ise; $\% 84^{\prime} 6$ 'sının sürekli kurumsal bakım hizmeti alan yaşlılardan oluşturduğu görülmektedir.

Incelenen tezlerin örneklem grubunun; hastalık/semptomlara göre özellikleri arasında konstipasyon tanısı alan, uyku sorunu yaşayan, Alzheimer tanısı alan, Kronik Obstrüktif Akciğer Hastalığı (KOAH) tanısı alan, kanser tanısı alan, diz osteartriti tanısı alan, katarakt ameliyatı geçiren ve sağıklı bireylerden oluştuğu saptanmıştır (Tablo 2).

Çalışma kapsamında incelenen tezlerde yaşlılarda farklı semptomlara yönelik kullanılan farmakolojik olmayan uygulamalar incelenmiştir ${ }^{21-46}$. Incelenen tezlerde en fazla ele alınan $(n=5)$ sorunlardan birinin konstipasyon olduğu ve 
Tablo 2. Yaşlılarda Farmakolojik Olmayan Uygulamalara Yönelik Türkiye'deki Mevcut Tezlerin Özellikleri (n=26)

\begin{tabular}{|c|c|c|c|c|c|c|}
\hline $\begin{array}{l}\text { Tezin } \\
\text { Türü/Yazar/yıl }\end{array}$ & $\begin{array}{l}\text { Örneklemin } \\
\text { özelliği/tanısı }\end{array}$ & Araştırma Deseni & $\begin{array}{l}\text { Örneklem } \\
\text { sayısı }\end{array}$ & $\begin{array}{l}\text { İncelenen } \\
\text { semptom(lar) }\end{array}$ & $\begin{array}{l}\text { Kullanılan farmakolojik } \\
\text { olmayan yöntem ve süresi }\end{array}$ & Uygulamanın etkisi \\
\hline $\begin{array}{l}\text { Doktora } \\
\text { Çevik } 2013\end{array}$ & $\begin{array}{l}\text { Konstipasyon } \\
\text { tanısı olan yaşlı } \\
\text { bireyler }\end{array}$ & Deneysel & 25 yaşlı birey & Konstipasyon & $\begin{array}{l}\text { Her ayağa } 15 \text { dakika olmak } \\
\text { üzere toplam } 30 \text { dakika ve } \\
\text { haftada iki seans olmak } \\
\text { üzere toplam sekiz seans } \\
\text { refleksoloji uygulanmıştır. }\end{array}$ & $\begin{array}{l}\text { Refleksolojinin dışkılama sayısı ve dışkı } \\
\text { miktarını arttırdığı, dışkı kıvamını, } \\
\text { dışkılama sırasında ıkınma ve dışkılama } \\
\text { sonrası tam boşalamama hissini azalttığı } \\
\text { saptanmıştır. }\end{array}$ \\
\hline $\begin{array}{l}\text { Doktora } \\
\text { Gürol Arslan } 2008\end{array}$ & $\begin{array}{l}\text { Konstipasyon } \\
\text { tanısı olan yaşlı } \\
\text { bireyler }\end{array}$ & Klinik deneysel & 35 yaşlı birey & Konstipasyon & $\begin{array}{l}\text { Castor yağı ile karın } \\
\text { bölgesine günde bir kez ( } 60 \\
\text { dk) olmak üzere } 3 \text { gün } \\
\text { kompres yapılmıştır. }\end{array}$ & $\begin{array}{l}\text { CYK'nin dışkılama sayısı ve dışkı miktarını } \\
\text { etkilemeksizin yaşıların konstipasyon } \\
\text { belirtilerinden dışkı kıvamını azalttığı, } \\
\text { dışkılama sırasında ıkınma ve dışılama } \\
\text { sonrası tam boşalamama hissini azalttığı } \\
\text { saptanmıştır. }\end{array}$ \\
\hline $\begin{array}{l}\text { Yüksek Lisans } \\
\text { Baran } 2015\end{array}$ & $\begin{array}{l}\text { Konstipasyon } \\
\text { tanısı olan yaşlı } \\
\text { bireyler }\end{array}$ & $\begin{array}{l}\text { Randomize kontrollü } \\
\text { deneysel }\end{array}$ & $\begin{array}{l}60 \text { gönüllü } \\
\text { yaşlı birey( } 30 \\
\text { deney grubu } \\
30 \text { kontrol grubu) }\end{array}$ & Konstipasyon & $\begin{array}{l}\text { Dört hafta boyunca her gün } \\
15 \mathrm{dk}^{\prime} \text { lık abdominal masaj } \\
\text { (bebek yağı ile) } \\
\text { uygulanmıştır }\end{array}$ & $\begin{array}{l}\text { Abdominal masajın yaşlıların büyük bir } \\
\text { kısmında etkili bir tedavi yöntemi } \\
\text { olduğu, herhangi bir yan etkisinin } \\
\text { olmadığı saptanmıştır. }\end{array}$ \\
\hline $\begin{array}{l}\text { Doktora } \\
\text { Olgun } 2015\end{array}$ & $\begin{array}{l}\text { Konstipasyon } \\
\text { tanısı olan yaşlı } \\
\text { bireyler }\end{array}$ & $\begin{array}{l}\text { Randomize kontrollü } \\
\text { çalışma }\end{array}$ & $\begin{array}{l}60 \text { yaşlı birey( } 30 \\
\text { masaj, } 30 \text { kontrol } \\
\text { grubu) }\end{array}$ & $\begin{array}{l}\text { Konstipasyon ve Yaşam } \\
\text { Kalitesi }\end{array}$ & $\begin{array}{l}\text { Haftada } 5 \text { gün ve } 10 \text { dakika } \\
\text { olmak üzere toplam } 2 \text { hafta } \\
\text { abdominal masaj } \\
\text { uygulanmıştır }\end{array}$ & $\begin{array}{l}\text { Abdominal masajın, konstipasyon } \\
\text { semptomlarının bazılarında ve yaşam } \\
\text { kalitesi üzerinde etkili olduğu } \\
\text { belirlenmiştir. }\end{array}$ \\
\hline $\begin{array}{l}\text { Yüksek Lisans } \\
\text { Altan } 2011\end{array}$ & $\begin{array}{l}\text { Bellek sorunu ve } \\
\text { ağır işitme kusuru } \\
\text { (sağılık) olmayan, } \\
\text { soruları bağımsız } \\
\text { yanıtlayabilen, } \\
\text { müzik dinletilen } \\
\text { süreçde daha } \\
\text { önce kullanılan } \\
\text { ilaçların dozunda } \\
\text { değişiklik } \\
\text { yapılmayan yaşlı } \\
\text { bireyler }\end{array}$ & $\begin{array}{l}\text { Kontrol grupsuz } \\
\text { öntest sontest } \\
\text { deneysel yarı } \\
\text { deneysel }\end{array}$ & 31 yaşlı birey & $\begin{array}{l}\text { Uyku Sorunları ve } \\
\text { Kalitesi }\end{array}$ & $\begin{array}{l}21 \text { gün boyunca her } \\
\text { akşamüstü 20:00 ve 21:00 } \\
\text { saatleri arasında yaşlıların } \\
\text { bir arada bulundukları } \\
\text { salona } \\
\text { duyabilecekleri düzeyde } \\
\text { uşşak makamı müziği yayını } \\
\text { yapılmıştır. }\end{array}$ & $\begin{array}{l}\text { Yaşlılarda akşam yatmadan önce } \\
\text { uygulanan pasif müzikoterapinin } \\
\text { uyku kalitesi üzerine olumlu etkileri } \\
\text { olduğu saptanmıştır. }\end{array}$ \\
\hline $\begin{array}{l}\text { Doktora } \\
\text { Gökalp } 2015\end{array}$ & $\begin{array}{l}\text { Kemoterapi } \\
\text { tedavisi alan, } \\
\text { hastalığın II. ve } \\
\text { III. evresinde } \\
\text { olan ve } \\
\text { hematolojik } \\
\text { kanser tanılı yaşlı } \\
\text { bireyler }\end{array}$ & $\begin{array}{l}\text { Ön test/son test } \\
\text { kontrollü yarı } \\
\text { deneysel }\end{array}$ & $\begin{array}{l}60 \text { hematolojik } \\
\text { kanser hastası } \\
\text { (30 kontrol ve } 30 \\
\text { deney grubu) }\end{array}$ & $\begin{array}{l}\text { Uyku Sorunları ve } \\
\text { Kalitesi }\end{array}$ & $\begin{array}{l}\text { Hastalara } 7 \text { gün boyunca } \\
\text { her gün gece } 20-23 \\
\text { saatleri arasında müzik } \\
\text { terapi yapılmıştır. (Hicaz, } \\
\text { Hüseyni ve Neva } \\
\text { makamında müzikler mp3 } \\
\text { çalar, kulaklık ile) }\end{array}$ & $\begin{array}{l}\text { Müzik terapinin hastaların uyku } \\
\text { kalitelerini arttırıp, } \\
\text { anksiyete düzeyini azalttığı } \\
\text { saptanmıştır. }\end{array}$ \\
\hline $\begin{array}{l}\text { Doktora } \\
\text { Akyar } 2010\end{array}$ & $\begin{array}{l}\text { Depresyon, } \\
\text { Parkinson ve } \\
\text { Uyku kalitesini } \\
\text { etkileyecek } \\
\text { hastalığı } \\
\text { olmayan yaşlı } \\
\text { bireyler }\end{array}$ & $\begin{array}{l}\text { Müdahale } \\
\text { Araştırması } \\
\text { Deneysel }\end{array}$ & 24 yaşlı birey & $\begin{array}{l}\text { Uyku Sorunları ve } \\
\text { Kalitesi }\end{array}$ & $\begin{array}{l}\text { Yaşlı bireylere } 30 \text { gün } \\
\text { boyunca her sabah } 08.30- \\
11.30 \text { saatleri arasında } 30 \\
\text { dk } 10.000 \text { lux şiddetinde } \\
\text { ışık tedavisi yapılmıştır. }\end{array}$ & $\begin{array}{l}\text { Işık tedavisinin sonunda ve } 1 \text { ay } \\
\text { sonrasında uyku kalitesinin artmasını } \\
\text { sağladığı saptanmıştır. }\end{array}$ \\
\hline $\begin{array}{l}\text { Yüksek Lisans } \\
\text { Düzgün } 2012\end{array}$ & Yaşlı birey & Deneysel & $\begin{array}{l}61 \text { yaşlı birey ( } 31 \\
\text { kontrol ve } 30 \\
\text { deney grubu) }\end{array}$ & $\begin{array}{l}\text { Uyku Sorunları ve } \\
\text { Kalitesi }\end{array}$ & $\begin{array}{l}\text { Yaşlılar } 5 \text { gün boyunca } \\
\text { saat } 8 \text { ile } 10 \text { saatleri } \\
\text { arasında (doğal güneş } \\
\text { ışığı) alabilecekleri bahçe } \\
\text { ortamında çıkarılmıştır }\end{array}$ & $\begin{array}{l}\text { Yaşlılarda doğrudan güneş ışığı } \\
\text { almanın uyku kalitesi üzerinde olumlu } \\
\text { etkisi olduğu saptanmıştır. }\end{array}$ \\
\hline
\end{tabular}


Tablo 2. Yaşlılarda Farmakolojik Olmayan Uygulamalara Yönelik Türkiye'deki Mevcut Tezlerin Özellikleri (n=26) (devamı)

\begin{tabular}{|c|c|c|c|c|c|c|}
\hline $\begin{array}{l}\text { Tezin } \\
\text { Türü/Yazar/yıl }\end{array}$ & $\begin{array}{l}\text { Örneklemin } \\
\text { özelliği/tanısı }\end{array}$ & Araştırma Deseni & $\begin{array}{l}\text { Örneklem } \\
\text { sayısı }\end{array}$ & $\begin{array}{l}\text { İncelenen } \\
\text { semptom(lar) }\end{array}$ & $\begin{array}{l}\text { Kullanılan farmakolojik } \\
\text { olmayan yöntem ve } \\
\text { süresi }\end{array}$ & Uygulamanın etkisi \\
\hline $\begin{array}{l}\text { Yüksek Lisans } \\
\text { Yaman } 2011\end{array}$ & $\begin{array}{l}\text { PUKi puanı } 5 \text { "in } \\
\text { üzerinde olan, } \\
\text { uyku kalitesi } \\
\text { "kötü" kabul } \\
\text { edilen yaşlı } \\
\text { bireyler }\end{array}$ & $\begin{array}{l}\text { Ön test-son test } \\
\text { deneme modelli } \\
\text { yarı deneysel }\end{array}$ & $\begin{array}{l}68 \text { yaşlı birey ( } 34 \\
\text { masaj, } 34 \\
\text { aromaterapi } \\
\text { grubu) }\end{array}$ & $\begin{array}{l}\text { Uyku Sorunları ve } \\
\text { Kalitesi }\end{array}$ & $\begin{array}{l}\text { Yaşlılara, yatma saatinden } \\
30 \text { dakika önce ve } 3 \text { gün } \\
\text { süreyle, gürültüden uzak, } \\
\text { Isısı } 23-25^{\circ} C^{\prime} \text { ye ayarlanmış } \\
\text { odada sırt masajı } \\
\text { yapılmıştır. }\end{array}$ & $\begin{array}{l}\text { Sırt masajının yaşlıların uyku } \\
\text { kalitesini yükselttiği ancak } \\
\text { aromaterapi sırt masajının yaşılıarın } \\
\text { uykusu üzerinde } \\
\text { daha etkili olduğu saptanmıştır. }\end{array}$ \\
\hline $\begin{array}{l}\text { Yüksek Lisans } \\
\text { Horuz } 2014\end{array}$ & $\begin{array}{l}\text { KOAH tanısı } \\
\text { almış bireyler }\end{array}$ & Deneysel & $\begin{array}{l}96 \text { birey ( } 32 \\
\text { klasik batı, } 32 \\
\text { Türk Müzik, } 32 \\
\text { kontrol grubu) }\end{array}$ & $\begin{array}{l}\text { Kan Basıncı, Solunum, } \\
\text { Nabız, oksijen } \\
\text { Saturasyonu }\end{array}$ & $\begin{array}{l}\text { MP3 çalar ile sabah } \\
\text { saatlerinde } 1^{\prime} \text { er saat } \\
\text { olmak üzere } 15 \text { gün } \\
\text { uygulanmıştır. }\end{array}$ & $\begin{array}{l}\text { Terapi sonucunda deney grubunda } \\
\text { kan basıncının azaldığı, nabız ve } \\
\text { solunum hızında fark olmadığı } \\
\text { saptanmışır. }\end{array}$ \\
\hline $\begin{array}{l}\text { Yüksek Lisans } \\
\text { Şahin Karadeniz } \\
2017\end{array}$ & $\begin{array}{l}\text { Demans - } \\
\text { alzheimer tanısı } \\
\text { almış yaşlı } \\
\text { bireyler }\end{array}$ & Deneysel & $\begin{array}{l}\text { Alzheimer tanısı } \\
\text { olan } 15 \text { deney } 15 \\
\text { kontrol } \\
\text { Huzurevinde }\end{array}$ & $\begin{array}{l}\text { Anksiyete ve } \\
\text { Ajitasyon }\end{array}$ & $\begin{array}{l}16 \text { hafta boyunca haftada } \\
\text { bir kez } 45 \text { dakikalık müzik } \\
\text { terapisi uygulanmıştır. }\end{array}$ & $\begin{array}{l}\text { Terapinin zihinsel, psikolojik, ajitasyon } \\
\text { ve anksiyeteyi azaltmada ve dengeli } \\
\text { hale getirmede olumlu etkisi olduğu } \\
\text { saptanmıştır. }\end{array}$ \\
\hline $\begin{array}{l}\text { Yüksek Lisans } \\
\text { Kurt } 2014\end{array}$ & $\begin{array}{l}\text { Sözel iletişim } \\
\text { kurabilen, tanısı } \\
\text { konmuş } \\
\text { psikiyatrik bir } \\
\text { rahatsızlığı ve } \\
\text { Demans, } \\
\text { Alzheimer gibi } \\
\text { bir hastalığı } \\
\text { olmayan } \\
\end{array}$ & Deneysel & $\begin{array}{l}38 \text { yaşlı birey (19 } \\
\text { deney, } 19 \\
\text { kontrol grubu) }\end{array}$ & Yalnızlık & $\begin{array}{l}\text { Etkinlik odasında toplu } \\
\text { halde, oturma } \\
\text { pozisyonunda } 10 \text { gün } \\
\text { boyunca sabah ve akşam } \\
\text { üzeri olmak üzere toplam } \\
20 \text { kez 30'ar dakika süre } \\
\text { ile çıplak kulakla Rast } \\
\text { makamındaki sözsüz } \\
\text { müzik dinletilmiştir. }\end{array}$ & $\begin{array}{l}\text { Müzik terapinin yalnızlık } \\
\text { hissini azaltma üzerine olumlu etkisi } \\
\text { olduğu saptanmıştır. }\end{array}$ \\
\hline $\begin{array}{l}\text { Doktora } \\
\text { Clark } 2014\end{array}$ & $\begin{array}{l}\text { Türkiye ve } \\
\text { ABD'de farklı } \\
\text { huzurevlerinde } \\
\text { yaşayan yaşlı } \\
\text { bireyler }\end{array}$ & Yarı deneysel & $\begin{array}{l}120 \text { yaşlı birey } \\
\text { ( } 60 \text { birey } \\
\text { Türkiye, } 60 \text { birey } \\
\text { ABD) }\end{array}$ & $\begin{array}{l}\text { Kullanılan farklı müzik } \\
\text { terapi yöntemlerinin } \\
\text { etkinliği ve müzik } \\
\text { açısından işlerliği }\end{array}$ & $\begin{array}{l}\text { Enstrüman çalma, müzikle } \\
\text { canlanan anıları resm } \\
\text { etme, müzikle } \\
\text { canlandırma akt. olmak } \\
\text { üzere ort.15 dk üç farklı } \\
\text { yöntem uygulamıştır. }\end{array}$ & $\begin{array}{l}\text { Müzik aktiviteleri sırasında yaşlıların } \\
\text { mutlu ve istekli olduğu, ancak cinsellik } \\
\text { konusunda kültürel farklılıklardan } \\
\text { dolayı ABD'de eşit katılım } \\
\text { gözlemlenirken Türkiye'de kadınların } \\
\text { daha çekingen olduğu saptanmıştır }\end{array}$ \\
\hline $\begin{array}{l}\text { Yüksek Lisans } \\
\text { Kaşlı } 2018\end{array}$ & $\begin{array}{l}\text { Toplumda } \\
\text { yaşayan, } \\
\text { yardımcı cihaz } \\
\text { kullanmadan } \\
\text { yürüyebilen yaşlı } \\
\text { bireyler }\end{array}$ & $\begin{array}{l}\text { Önce-sonra } \\
\text { ölçümlü randomize } \\
\text { kontrollü } \\
\text { Deneysel }\end{array}$ & $\begin{array}{l}52 \text { yaşlı birey ( } 26 \\
\text { deney, } 26 \\
\text { kontrol grubu) }\end{array}$ & Eklem açıklığı & $\begin{array}{l}\text { Fizyoterapist tarafından } \\
60 \text { saniye boyunca, } 15 \\
\text { saniye dinlenme araları ile } \\
\text { gastrosinemius kasına } 3 \\
\text { kez tekrarlanarak } \\
\text { uygulanmıştır }\end{array}$ & $\begin{array}{l}\text { Uygulamanın yaşlı bireylerde eklem } \\
\text { hareketi değişimlerinde artışa neden } \\
\text { olduğu ve bu etkinin } 20 \text { dakikaya kadar } \\
\text { sürdüğü saptanmıştır. }\end{array}$ \\
\hline $\begin{array}{l}\text { Doktora } \\
\text { Pehlivan } 2015\end{array}$ & $\begin{array}{l}\text { Diz osteoartriti } \\
\text { olan yaşlı } \\
\text { bireyler }\end{array}$ & $\begin{array}{l}\text { Randomize ön test- } \\
\text { son test kontrollü } \\
\text { Deneysel }\end{array}$ & $\begin{array}{l}90 \text { yaşlı birey (30 } \\
\text { aromaterapi } \\
\text { masajı,30 } \\
\text { plasebo masaj, } \\
30 \text { kontrol } \\
\text { grubu) }\end{array}$ & $\begin{array}{l}\text { Ağrı, fonksiyonel } \\
\text { durum ve yaşam } \\
\text { kalitesi }\end{array}$ & $\begin{array}{l}\text { Üç haftalık sürede haftada } \\
2 \text { olmak üzere toplam } 6 \\
\text { seans aromaterapi masajı } \\
\text { uygulanmıştır. }\end{array}$ & $\begin{array}{l}\text { Aromaterapinin ağrı, fonksiyonel } \\
\text { durum ve yaşam kalitesi üzerine } \\
\text { olumlu etkisinin olduğu saptanmıştır. }\end{array}$ \\
\hline $\begin{array}{l}\text { Yüksek Lisans } \\
\text { Birer } 2015\end{array}$ & $\begin{array}{l}\text { Katarakt } \\
\text { ameliyatı } \\
\text { yapılmak için } \\
\text { hastane yatışı } \\
\text { yapılan hastalar }\end{array}$ & $\begin{array}{l}\text { Randomize } \\
\text { kontrollü girişim } \\
\text { çalışması } \\
\text { Deneysel }\end{array}$ & $\begin{array}{l}114 \text { birey ( } 57 \\
\text { deney, } 57 \\
\text { kontrol grubu) }\end{array}$ & $\begin{array}{l}\text { Anksiyete ve hasta } \\
\text { memnuniyeti } \\
\text { (katarakt ameliyatı } \\
\text { sırasında yaşanan) }\end{array}$ & $\begin{array}{l}\text { Girişim grubundaki } \\
\text { hastalara ameliyat } \\
\text { esnasında 15dk süre ile } \\
\text { terapötik dokunma } \\
\text { uygulanmıştır }\end{array}$ & $\begin{array}{l}\text { Terapötik dokunmanın hastaların } \\
\text { anksiyetesini düşürdüğü, vital } \\
\text { bulguları olumlu yönde etkilediği ve } \\
\text { hasta memnuniyetini arttırdığı } \\
\text { saptanmıştır. }\end{array}$ \\
\hline $\begin{array}{l}\text { Doktora } \\
\text { Kuru } 2016\end{array}$ & $\begin{array}{l}\text { Yatağa bağımlı } \\
\text { olmayan ve } \\
\text { günlük yaşam } \\
\text { aktv. yerine } \\
\text { getirebilen yaşlı } \\
\text { bireyler }\end{array}$ & $\begin{array}{l}\text { Ön test-son test } \\
\text { kontrol gruplu yarı } \\
\text { deneysel }\end{array}$ & $\begin{array}{l}65 \text { yaşlı birey ( } 32 \\
\text { deney, } 32 \\
\text { kontrol grubu) }\end{array}$ & Yaşam Kalitesi & $\begin{array}{l}\text { Haftada } 2 \text { gün toplamda } \\
21 \text { oturum olmak üzere } \\
\text { gülme terapisi } \\
\text { uygulanmıştır. }\end{array}$ & $\begin{array}{l}\text { Gülme terapisinin yaşam kalitesi } \\
\text { puanlarını anlamlı düzeyde artırdığı } \\
\text { saptanmıştır. }\end{array}$ \\
\hline
\end{tabular}


Tablo 2. Yaşıılarda Farmakolojik Olmayan Uygulamalara Yönelik Türkiye'deki Mevcut Tezlerin Özellikleri (n=26) (devamı)

\begin{tabular}{|c|c|c|c|c|c|c|}
\hline $\begin{array}{l}\text { Tezin } \\
\text { Türü/Yazar/yıl }\end{array}$ & $\begin{array}{l}\text { Örneklemin } \\
\text { özelliği/tanısı }\end{array}$ & Araştırma Deseni & $\begin{array}{l}\text { Örneklem } \\
\text { sayısı }\end{array}$ & $\begin{array}{l}\text { İncelenen } \\
\text { semptom(lar) }\end{array}$ & $\begin{array}{l}\text { Kullanılan farmakolojik } \\
\text { olmayan yöntem ve süresi }\end{array}$ & Uygulamanın etkisi \\
\hline $\begin{array}{l}\text { Doktora } \\
\text { Ercan Şahin } \\
2015\end{array}$ & $\begin{array}{l}\text { İletişim kurabilen, } \\
\text { işitme sorunu } \\
\text { olmayan, demansı } \\
\text { ve psikiyatrik } \\
\text { sorunu olmayan } \\
\text { yaşlı bireyler } \\
\end{array}$ & $\begin{array}{l}\text { Tek grupta ön } \\
\text { ve son test desenli } \\
\text { yarı deneysel }\end{array}$ & 32 yaşlı birey & Yaşam Kalitesi & $\begin{array}{l}\text { Gruplara ayrılan yaşlılara } \\
45-60 \mathrm{dk} \text { süreyle toplam } 12 \\
\text { oturumluk çocukluk, } \\
\text { arkadaşlık, evlilik vb. } \\
\text { konularda anımsama } \\
\text { terapisi uygulanmıştır. }\end{array}$ & $\begin{array}{l}\text { Anımsama terapisi uygulaması sonrası } \\
\text { yaşam kalitesi ölçeği alt alan ve genel } \\
\text { skor puanlarının, ön test puanlarına göre } \\
\text { düştüğü saptanmıştır. }\end{array}$ \\
\hline $\begin{array}{l}\text { Doktora } \\
\text { Erdoğan } 2013\end{array}$ & $\begin{array}{l}\text { Geriatrik } \\
\text { Depresyon } \\
\text { Ölçeği'nden } 14 \text { ve } \\
\text { üstünde, Mini } \\
\text { Mental Testten } 21 \\
\text { ve üstünde pn } \\
\text { alan; kronik ağrıya } \\
\text { sahip olan bireyler }\end{array}$ & $\begin{array}{l}\text { Randomize } \\
\text { kontrollü, çift körlü } \\
\text { ve deneysel }\end{array}$ & $\begin{array}{l}90 \text { yaşlı birey ( } 30 \\
\text { deney, } 30 \text { yalancı } \\
\text { reiki ve } 30 \text { kontrol } \\
\text { grubu) }\end{array}$ & $\begin{array}{l}\text { Ağrı, Yaşam Kalitesi ve } \\
\text { depresyon }\end{array}$ & $\begin{array}{l}\text { Sekiz hafta boyunca haftada } \\
\text { bir kez, } 45 \mathrm{dk}-1 \text { saat } \\
\text { arasında reiki uygulanmıştır. }\end{array}$ & $\begin{array}{l}\text { Girişimin yaşlı bireylerin, yalancı reiki ve } \\
\text { kontrol grubuna göre ağrı ve depresyon } \\
\text { puanlarında anlamlı azalma, yaşam } \\
\text { kalitesi puanlarında ise artma olduğu } \\
\text { saptanmıştır. }\end{array}$ \\
\hline $\begin{array}{l}\text { Doktora } \\
\text { Özdemir } 2007\end{array}$ & $\begin{array}{l}\text { Hafif Alzheimer } \\
\text { hastası yaşlı } \\
\text { bireyler }\end{array}$ & Yarı deneysel & 27 yaşlı birey & $\begin{array}{l}\text { Depresyon ve } \\
\text { anksiyete kognitif } \\
\text { durumu, }\end{array}$ & $\begin{array}{l}\text { Haftada } 4 \text { gün olmak üzere } \\
\text { Müzik terapisi, nesne-canlı } \\
\text { resmi boyama ve kişi-yer- } \\
\text { zaman yöntemleri } \\
\text { kullanılmıştır. }\end{array}$ & $\begin{array}{l}\text { Girişimin kognitif durum, depresyon ve } \\
\text { anksiyete üzerine olumlu etkisinin } \\
\text { olduğu, bu etkinin müdahale bittikten } 3 \\
\text { hafta sonra azalma eğilimi ile devam } \\
\text { ettiği saptanmıştır. }\end{array}$ \\
\hline $\begin{array}{l}\text { Yüksek Lisans } \\
\text { Turan } 2015\end{array}$ & $\begin{array}{l}\text { Demans, } \\
\text { Alzheimer ve } \\
\text { herhangi bir ağır } \\
\text { kronik rahatsızlığı } \\
\text { olmayan }\end{array}$ & Deneysel & $\begin{array}{l}22 \text { yaşlı birey (11 } \\
\text { deney, } 11 \text { kontrol } \\
\text { grubu) }\end{array}$ & $\begin{array}{l}\text { Depresyon ve } \\
\text { Anksiyete }\end{array}$ & $\begin{array}{l}5 \text { haftalık süreyle toplam } 10 \\
\text { gün yemek terapisi } \\
\text { uygulanmıştır. }\end{array}$ & $\begin{array}{l}\text { Terapi programının hem depresyon, hem } \\
\text { de anksiyete düzeylerini düşürmede } \\
\text { etkili olduğu saptanmıştır. }\end{array}$ \\
\hline $\begin{array}{l}\text { Yüksek Lisans } \\
\text { Uzakgören } 2015\end{array}$ & $\begin{array}{l}\text { Standardize Mini } \\
\text { Mental Test } \\
\text { sonucundan } 24 \\
\text { puan ve üstü alan } \\
\text { ve eğitim } \\
\text { seviyeleri benzer } \\
\text { bireyler }\end{array}$ & $\begin{array}{l}\text { Ön-test/ son test, } \\
\text { Kontrol ve deney } \\
\text { gruplu Deneysel }\end{array}$ & $\begin{array}{l}133 \text { yaşı birey (66 } \\
\text { kişinin deney, } 67 \\
\text { kişi kontrol grubu) }\end{array}$ & $\begin{array}{l}\text { Bellek performansı, } \\
\text { Benlik saygısı, Yaşam } \\
\text { Kalitesi }\end{array}$ & $\begin{array}{l}\text { Dans eğitmenleri eşliğinde } \\
10 \mathrm{dk} \text { ısınma, } 25 \mathrm{dk} \text { salsa } \\
\text { dansı olmak üzere } 2 \text { aylık } \\
\text { dans eğitimi yapılmıştır. }\end{array}$ & $\begin{array}{l}\text { Dans eğitiminin bellek performansına, } \\
\text { yaşam kalitesine ve benlik } \\
\text { saygısına olumlu etki sağladığı } \\
\text { saptanmıştır. }\end{array}$ \\
\hline $\begin{array}{l}\text { Doktora } \\
\text { Yücel } 2008\end{array}$ & $\begin{array}{l}\text { DSÖ’nün önerdiği } \\
\text { Sağlığın Uygunluk } \\
\text { Düzeyine göre } \\
\text { Grup } 1 \text { ve } 2 \text { 'de } \\
\text { olan yaşlı bireyler }\end{array}$ & Yarı deneysel & $\begin{array}{l}\text { Huzurevinde } \\
\text { yaşayan } 34 \text {, evde } \\
\text { yaşayan } 33 \text { yaşlı } \\
\text { birey }\end{array}$ & $\begin{array}{l}\text { Fiziksel performans, } \\
\text { depresyon, kognitif } \\
\text { bulgular ve yaşam } \\
\text { kalitesi }\end{array}$ & $\begin{array}{l}\text { El, lokomotor ve kognitif } \\
\text { aktiviteler olmak üzere üç } \\
\text { grup aktivite haftada iki gün, } \\
\text { her seans } 45 \text { dakika süre ile } \\
\text { toplam } 12 \text { hafta } \\
\text { uygulanmıştır }\end{array}$ & $\begin{array}{l}\text { Girişim sonrasında ev grubunda fiziksel } \\
\text { performans seviyesi ve yaşam kalitelerinin } \\
\text { ve her iki grupta depresyon seviyelerinin } \\
\text { azaldığı saptanmıştır. }\end{array}$ \\
\hline
\end{tabular}


konstipasyona yönelik; refleksoloji ve masaj yöntemlerinin uygulandığı ve tamamının konstipasyon üzerinde etkili olduğu saptanmıştır (Tablo 2).

Yaşlılarda; en fazla incelenen $(n=5)$ bir diğer sorunun uyku sorunları ve uyku kalitesi olduğu ve bu soruna yönelik yapılan girişimler arasında; müzik terapisi, ışık tedavisi ve masaj uygulandığı ve sonuçlarının etkili olduğu belirlenmiştir (Tablo 2).

Tezlerde kullanılan farmakolojik olmayan yöntemler arasında en fazla kullanılan yöntemin müzik terapisi $(n=7)$ olduğu görülmektedir. Müzik terapisi uygulaması ile yaşlılarda kan basıncı, solunum, nabız, oksijen saturasyonu; anksiyete ve ajitasyon; konfor ve anksiyete; yalnızlık ve aktivite katılım düzeyine etkisinin incelendiği ve etkili olduğu saptanmıştır (Tablo 2).

Çalışmada farmakolojik olmayan refleksoloji, yağ ile kompres, abdominal masaj, aroma masajı, müzikoterapinin yöntemlerinin; ağrı, anksiyete, depresyon, benlik saygısı, yaşam kalitesi gibi semptomlar üzerinde etkili olduğu belirlenmiştir.

\section{TARTIŞMA}

Dünyada yaşlı sağlığına ilişkin sorunların çözümünde farmakolojik olmayan yöntemler birçok farklı disiplin tarafından kullanılmaktadır. Bu çalışma kapsamında da incelenen 26 tezin farklı bilim dalları tarafından (hemşirelik, halk sağlığı, Türk musikisi, radyo televizyon sinema, klinik psikoloji, psikoloji, iş ve uğraşı tedavisi, geriatrik fizyoterapi) yürütüldüğü görülmektedir. Tezlerin yarıdan fazlasının $(n=20)$ hemşirelik alanında yürütülmesi ise yaşlı bakımında temel rol alan hemşirelik disiplinine ilişkin önemli bir bulgudur. Yaşlılıkta artan kronik sorunlarla birlikte eş kaybı, emeklilik, ölüm korkusu, içe kapanma gibi psikososyal sorunlar da görülmektedir ${ }^{47,48}$. Bu sorunlar ve sorunların çözümüne yönelik bakım gereksinimleri göz önüne alındığında yaşlılık döneminde bütüncül hemşirelik bakımının önemi ortaya çıkmaktadır. Bu çalışmada hemşirelik bakımın önemini destekler niteliktedir.

Incelenen tezlerde yaşlılıkta en fazla karşılaşılan sağlık sorunlarından biri olan konstipasyon ve beraberinde uyku bozuklukları, eklem ağrısı ve anksiyete sorunlarında masaj uygulamasının_kullanıldığı ve masajın bu sorunlar üzerinde etkili olduğu saptanmıştır ${ }^{22-25,30,36}$. Masaj; farmakolojik olmayan, düşük riskli, düşük maliyetli etkili bir dokunma hareketi olarak etkili olmasının yanı sıra kan ve lenfatik dolaşımı düzenleme, kas tonüsünü iyileştirebilme, kan basıncını dengeleme, ağrıyı azaltma, uykusuzluğu azaltma, hareket aralığını artırma ve demans ile ilişkili ajitasyonu iyileştirebilme, anksiyeteyi azaltma gibi birçok farklı sorunda etkili olduğu belirtilmektedir ${ }^{49,50}$. Bu çalışmada da literatürle uyumlu olarak benzer sonuçlar elde edilmiştir.

Yaşılıarın sıklıkla karşılaştığı bir diğer sorun olan uyku sorunlarının; incelenen tezlerde en fazla ele alınan $(n=5)$ sorunlardan biri olduğu saptanmıştır. Uyku bozukluklarının tedavisi için; tai chi egzersizi, sanat terapisi, farkındalık uygulaması ve müzik anımsama terapisini içeren çoklu uyaranların kullanıldığı bir çalışmada yaşlılarda uyku bozukluğunun anlamlı derecede azaldığı ve bu tip psikososyal müdahalelerin uyku bozuklukları ile baş etmede önemli farmakolojik olmayan uygulamalar olduğu belirtilmiştir ${ }^{51}$. Benzer şekilde çalışma kapsamında incelenen tezlerde uyku sorunun çözümü için müzik terapisi, ışık tedavisi ve masaj uygulandığı ve sonuçlarının etkili olduğu görülmektedir26,30.

Yaşlıların karşılaştığı diğer sorunların arasında yüksek kan basıncı, ortopedi ameliyatları sonrası ağrı gibi fizyolojik sorunlar ile anksiyete, yalnızlık gibi psikolojik sorunların olduğu ve bu sorunlarla baş etmede müzik terapisinin geniş bir yelpazede kullanıldığı ve etkili olduğu_belirtilmektedir ${ }^{52-}$ 55. Incelenen tezlerde de farmakolojik olmayan yöntemler arasında en fazla kullanılan yöntemin müzik terapisi olduğu ve müzik terapisinin kan basıncı, solunum, nabız, oksijen saturasyonu, anksiyete, ajitasyon; konfor ve yalnızlık düzeyine vb. semptom ve diğer faktörler üzerinde etkili olduğu görülmektedir26,27,31-34. Bu sonuçların müzik terapisinin ucuz, invaziv olmayan, nonfarmakolojik ve holistik bakım girişimlerini içeren bir uygulama olmasından kaynaklı olduğu düşünülebilir.

Yaşlılarda tedavisi zor olan depresyonda farmakolojik olmayan yöntemler arasında, meditasyon, gevşeme teknikleri, egzersiz, bilişsel davranışsal terapi, problem çözme terapisi, anımsama terapisi gibi aktivitelerin yapılması önerilmektedir ${ }^{56-58}$. Bu incelemede de literatürle uyumlu olarak; depresyon, anksiyete, kaygı, yalnızlık gibi psikososyal sorunların iyileştirilmesinde anımsama terapisi, reiki, çoklu duyusal uyaran, yemek terapisi, çok amaçlı aktivite eğitimi uygulandığı ve bu uygulamaların depresyon üzerinde olumlu etkisinin olduğu saptanmıştır.

\section{SONUÇ ve ÖNERILER}

Yaşlılık döneminde fiziksel ve psikososyal alanlarda yaşanan sorunların çözümünde farmakolojik olmayan yöntemlerin önemli olduğu ve sıklıkla kullanıldığı bilinmektedir. Bu çalışmada incelenen tezlerde de kullanılan farklı farmakolojik olmayan uygulamaların yaşlanmayla birlikte sık görülen semptomların yönetiminde olumlu etkileri olduğu ve bakımın kalitesini artırdığı belirlenmiştir. Türkiye'de yaşlılara yönelik yapılan farmakolojik olmayan uygulamalar ve uygulamaların semptomlara etkilerine yönelik yapılan tezlerin incelendiği bu çalışmada tezlerin çoğunluğunun hemşirelik alanında yürütüldüğü saptanmıştır. Bu sonuç bakım felsefesini temel alan bir meslek olan hemşirelikte farmakolojik olmayan uygulamaların önemli bir yere sahip olduğunu göstermektedir. Araştırmadan elde edilen sonuçların yapılacak olan çalışmalara yön vermesi açısından katkı sağlayacağı düşünülmektedir. Bu çalışmanın teori ile uygulamayı birleştirerek farmakolojik olmayan uygulamalara bilimsel bir temel oluşturmada katkı sağlayacağı düşünülmektedir. Bu çalışmadan yola çıkarak yaşlıların bakım gereksinimlerine yönelik multidisipliner yaklaşımlı kanıta dayalı randomize kontrollü çalışmalara odaklanılması önerilebilir.

Etik Kurul Onayı: Bu çalışmada, Yüksek Öğretim Kurumu ulusal tez merkezinden erişim izni olan 33 tez kullanılmış, erişim izni olmayan 7 tezin tam metnine ulaşılamadığı için çalışmaya dahil edilmemiş ve toplam 26 tez değerlendirilmiştir. Bu doğrultuda etik kurul izni alınmasına gerek duyulmamıştır. 
Çıkar Çatışması: Yoktur.

Finansal Destek: Bildirilmemiştir.

Yazar katkıları:

Araştırma dizaynı: KÖ, GM

Veri toplama: KÖ, GM, GKÖ

Literatür araştırması: KÖ, GM, GKÖ

Ethics Committee Approval: In this study, 33 theses that have access permitted in the National Thesis Center of the Higher Education Institution were used. Since the full text of 7 theses without access permission was not available, they were not included in the study. A total of 26 theses were evaluated. In line with these, there was no need for an ethics committee approval.

Confict of Interest: Not reported.

Funding: None.

Author contributions:

Study design: KÖ, GM

Data collection: KÖ, GM, GKÖ

Literature search: KÖ, GM, GKÖ

Drafting manuscript: KÖ, GM, GKÖ

\section{KAYNAKLAR}

1. Saxon SV, Perkins EA, Etten MJ. Complementary, alternative, and integrative medicine. In: Physical change and aging : a guide for the helping professions. 6th ed. New York, NY: Springer Publishing Company. [Internet]. 2015 [Erişim Tarihi: 15 Temmuz 2019]. Erişim

Adresi: http://search.ebscohost.com/login.aspx?direct=true\& $\mathrm{db}=\mathrm{e} 000 \mathrm{xw} w \& A \mathrm{~N}=835739$ \&lang=tr\&site=ehost-live .

2. World Health Organization (WHO). Global report on traditional and complementary medicine 2019;15-28.

3. Effoe VS, Suerken CK, Quandt SA, Bell RA, Arcury TA. The association of complementary therapy use with prescription medication adherence among older community-dwelling adults. J Appl Gerontol. 2017;36(9):1054-1069.

4. Ünsal A. Türk kültüründe geleneksel hasta bakımı: Anadolu örneği. Yüzüncü Yıl Sosyal Bilimler Enstitüsü Dergisi. 2017;1(2):87-98.

5. Gök Metin Z, Karadas C, Özdemir L. Complementary and alternative therapies from the Turkish Physician's perspective: An embedded mixed-method study. Complementary Therapies in Clinical Practice. 2020;101144.

6. Kutlutürkan S, Karataş T. Kemoterapiye Bağlı Kusmada Tamamlayıcı Tıp. Bozok Tıp Dergisi. 2014;4(3):63-65.

7. Şaş S, Büyükturan Ö, Büyükturan B. Kas İskelet Sistemi Hastalıklarında Tamamlayıcı ve Alternatif Tıp Yöntemleri Kullanım Sıklığının Değerlendirilmesi. Sakarya Tıp Dergisi. 2018;8(3):481-488.

8. Yazıcı SÖ, Kalaycı İ. Yaşlı Hastaların Günlük Yaşam Aktivitelerinin Değerlendirilmesi. Mühendislik Bilimleri ve Tasarım Dergisi. 2015;3(3):385-39.

9. Erdoğan Z, Atik D, Çınar S. Kronik Böbrek Yetmezliğinde Tamamlayıcı ve Alternatif Tıp Yöntemlerinin Kullanımı. Arşiv Kaynak Tarama Dergisi. 2014;23(4):773-789.

10. Erdoğan Z, Akıncı A, Yavuz D, Tosun Z, Atik D. Huzurevinde Kalan Yaşlılarda Tamamlayıcı ve Alternatif
Tıp Yöntemlerini Kullanma Durumu. Kafkas Tıp Bilimleri Dergisi. 2017;7(1):60-66.

11. Dedeli Ö, Karadakovan A. Yaşlı Bireylerde ilaç Kullanımı, Tamamlayıcı ve Alternatif Tedavi Uygulamalarının İncelenmesi. Spatula Dergisi. 2011;1(1):23-32.

12. Sağkal $T$, Demiral $S$, Odabaş $H$, Altunok E. Kırsal Kesimde Yaşayan Yaşlı Bireylerin Tamamlayıcı ve Alternatif Tedavi Yöntemlerini Kullanma Durumları. Fırat Üniversitesi Sağlık Bilimleri Tıp Dergisi. 2013;27(1):19-26.

13. Yang $M$, Jiang $L$, Wang $Q$, Chen $H, X u$ G. Traditional Chinese medicine for knee osteoarthritis: an overview of systematic review. PloS One. 2017;12(12):1-16.

14. Caresearch Palliative Care Knowledge Network. Non Pharmacological Approaches. [Internet]. 2019 [Erişim Tarihi: 31 Ekim 2019]. Erişim Adresi: https://www.caresearch.com.au/caresearch/ClinicalPr actice/Physical/Pain/NonPharmacologicalApproaches/ tabid/751/Default.aspx

15. Eliopoulos C. Integration of complementary and alternative therapies in geriatric care Medscape Nurse. [Internet]. 2006 [Erişim Tarihi: 18 Mayıs 2019]. Erişim Adresi: http://www.medscape.com/viewarticle/542207

16. Ebersole P, Touhy TA. Geriatric Nursing : Growth of a Specialty. New York: Springer Publishing Company. [Internet]. 2006 [Erişim Tarihi: 5 Aralık 2019]. Erişim Adresi:http://search.ebscohost.com/login.aspx?direct $=$ true $\& \mathrm{db}=$ nlebk $\& A N=181758 \&$ lang=tr $\&$ site $=$ ehost live

17. Terzi H, Kitiş Y. Yaşlı bireylerde ilaç kullanımı ve tamamlayıcı alternatif terapi uygulamaları. İçinde: Bilgili N, Kitiş Y, editörler. Yaşlılık ve Yaşlı Sağlığı. 1 baskı. Ankara: Vize Yayıncılık; 2017;463-465.

18. Complementary, alternative, or integrative health: what's in a Name? National Center on Complementary and Integrative Health-NCCIH. [Internet]. 2019 [Erişim Tarihi: 2 Nisan 2019]. Erişim Adresi: https://nccih.nih.gov/health/integrative-health\#hed5

19. İnan FŞ, Üstün B, Bademli K. Türkiye'de kuram/modele dayalı hemşirelik araştırmalarının incelenmesi. Anadolu Hemşirelik ve Sağlık Bilimleri Dergisi. 2013;16(2):132-39.

20. Ardahan M, Özsoy S. Türkiye'de hemşirelik araştırmalarındaki eğilimler: yüksek lisans ve doktora tezleri üzerine bir çalışma. Gümüşhane Üniversitesi Sağlık Bilimleri Dergisi. 2015;4(4):516-34.

21. Çevik K. Yaşlılarda Refleksoloji Uygulamasının Konstipasyon Üzerine Etkisi [Doktora tezi].Izmir: Ege Üniversitesi; 2013.

22. Gürol Arslan G. Yaşılırda Karına Castor Yağı Kompresi Uygulamanın Konstipasyona Etkisinin İncelenmesi [Doktora tezi]. İzmir: Ege Üniversitesi; 2008.

23. Baran A. Yaşılıarda Konstipasyon Yönetiminde Abdominal Masajın Etkisi: Randomize Kontrollü Çalışma [Doktora tezi]. İstanbul: Üsküdar Üniversitesi; 2015. 
24. Lafçı D. Aroma Masajının Yaşlılardaki Konstipasyona Etkisi [Doktora tezi]. Erzurum: Atatürk Üniversitesi; 2014.

25. Olgun S. Huzurevinde Yaşayan Yaşlılarda Abdominal Masajın Kronik Konstipasyona ve Yaşam Kalitesine Etkisi [Doktora tezi]. İzmir: Ege Üniversitesi; 2013.

26. Altan N. Huzurevinde Kalan Yaşlılarda Pasif Müzikoterapinin Uyku Kalitesine Etkisi [Yüksek Lisans tezi]. İstanbul: Marmara Üniversitesi; 2011.

27. Gökalp K. Müzik Terapisinin Yaşı Kanser Hastalarının Anksiyete Ve Uyku Kalitesi Üzerine Etkisi [Doktora tezi]. Erzurum: Atatürk Üniversitesi; 2015.

28. Akyar i. Yaşlı Bireylerde Işık Tedavisinin Uyku Kalitesi Üzerine Etkisi [Doktora tezi]. Ankara: Hacettepe Üniversitesi; 2010.

29. Düzgün G. Huzurevinde Kalan Yaşlılarda Parlak Işık (Doğal Güneş Işığı) Tedavisinin Uyku Sorunları ve Uyku Kalitesi Üzerine Etkisinin İncelenmesi [Doktora tezi]. İzmir: Ege Üniversitesi; 2012.

30. Yaman S. Lavanta Yağıyla Uygulanan Sırt Masajının Yaşlıların Uyku Kalitesine Etkisinin İncelenmesi [Yüksek Lisans tezi]. Elazığ: Fırat Üniversitesi; 2011.

31. Horuz D. Göğüs Hastalıkları Servisinde Yatan Hastalarda Müzik Terapisinin Anksiyete ve Bazı Klinik Bulgulara Etkisi [Yüksek Lisans tezi]. Zonguldak: Bülent Ecevit Üniversitesi; 2014.

32. Şahin Karadeniz E. Demans-Alzheimer Hastalarında Farklı Müzik Terapi Uygulamalarının Zihinsel, Psikolojik, Anksiyete ve Ajitasyon Etkileri Üzerine Karşılaştırmalı Çalışma [Doktora tezi]. İstanbul: Haliç Üniversitesi; 2017.

33. Yaşar E. Huzurevinde Yaşayan Yaşlılarda Müziğin Konfor ve Anksiyeteye Etkisi [Yüksek Lisans tezi]. İzmir: Ege Üniversitesi; 2014.

34. Kurt D. Müzik Terapinin Huzurevinde Yaşayan Yaşlıların Yalnızlık Hissi Üzerine Etkisi [Yüksek Lisans tezi]. İstanbul: Marmara Üniversitesi; 2014.

35. Clark A. Görsel İşitsel Yapımlarda Müziğin Yaşlılık Terapisine Etkileri, Türkiye, Abd Örneğinde Karşılaştırılmalı Uygulamaları [Doktora tezi]. İstanbul: İstanbul Üniversitesi; 2014.

36. Kaşı K. Yaşlılarda Roller Massage (Silindir Masajı) Uygulaması İle Yapılan Miyofasyal Gevşeme Tekniğinin Ayak Bileği Eklem Açıklığına Etkisi [Yüksek Lisans tezi]. İzmir: Dokuz Eylül Üniversitesi; 2018.

37. Pehlivan S. Diz Osteoartritli Yaşlı Bireylere Uygulanan Aromaterapi Masajının Ağrı, Fonksiyonel Durum Ve Yaşam Kalitesine Etkisi [Doktora tezi]. İmir: Ege Üniversitesi; 2015.

38. Birer Z. Katarakt Ameliyatı Esnasında Uygulanan Terapötik Dokunmanın Anksiyete ve Hasta Memnuniyetine Etkisi [Yüksek Lisans tezi]. Manisa: Celal Bayar Üniversitesi; 2015.

39. Kuru N. Gülme Terapisinin Huzurevinde Kalan Bireylerin Yaşam Kalitesine Etkisi [Doktora tezi]. Ankara: Hacettepe Üniversitesi; 2016.

40. Ercan Şahin N. Huzurevinde Yaşayan Yaşlılara Uygulanan Anımsama Terapisinin Yaşlıların Yaşam
Kalitesine Etkisi [Doktora tezi]. Ankara: Hacettepe Üniversitesi; 2015.

41. Duru Aşiret G. Anımsama Terapisinin Alzheimer Hastalarının Bilişsel Durumu, Depresyon ve Günlük Yaşam Faaliyetlerine Etkisi [Doktora tezi]. Ankara: Hacettepe Üniversitesi; 2014.

42. Erdoğan Z. Huzurevinde Kalan Yaşlılarda Reikinin Ağrı, Yaşam Kalitesi ve Depresyon Üzerine Etkisi [Doktora tezi]. İstanbul: Marmara Üniversitesi; 2013.

43. Özdemir L. Hafif Alzheimer Hastalarına Uygulanan Çoklu Duyusal Uyaran Yönteminin Kognitif Durum, Depresyon ve Anksiyete Üzerine Etkisi [Doktora tezi]. Ankara: Hacettepe Üniversitesi; 2007.

44. Turan F.G. Bir İş-Uğraş Terapisi Olarak Yemek Terapisinin Huzurevinde Yaşayan Kadın Yaşlılarda Ortaya Çıkan Depresyon ve Anksiyete Düzeyleri Üzerindeki Etkisinin İncelenmesi [Yüksek Lisans tezi]. İstanbul: Beykent Üniversitesi; 2015.

45. Uzakgören P. Yaşlılarda Fiziksel Bir Aktivite Olarak Dans Eğitiminin, Bellek Performansı, Benlik Saygısı ve Yaşam Kalitesi Üzerinde Yarattı̆̆ Değişikliklerin İncelenmesi [Yüksek Lisans tezi]. İzmir: Ege Üniversitesi; 2015.

46. Yücel H. Evde ve Huzurevindeki Yaşlılarda Çok Amaçlı Aktivite Eğitiminin Etkinliğinin Karşılaştırılması [Doktora tezi]. Ankara: Hacettepe Üniversitesi; 2008.

47. Tezel A. Yaşlanmaya bağlı fizyolojik değişimler. İçinde: Bilgili N, Kitiş Y, editörler. Yaşlılık ve Yaşlı Sağlığı. 1 baskı. Ankara: Vize Yayıncılık; 2017;76-86.

48. Er D. Psikososyal açıdan yaşlılık. Fırat Sağlık Hizmetleri Dergisi. 2009;11(4):131-44.

49. Tusaie K. Overview of complementary/Alternative approaches. In: Tusaie K, Fitzpatrick JJ. Editors. Advanced Practice Psychiatric Nursing: Integrating Psychotherapy, Psychopharmacology, and Complementary and Alternative Approaches. New York: Springer Publishing Company. [Internet]. 2012 [Erişim Tarihi: 28 Mayıs 2019]. Erişim Adresi: http://search.ebscohost.com/login.aspx?direct=true\& $\mathrm{db}=$ nlebk\&AN=484468\&lang=tr\&site=ehost-live

50. Çınar Ş, Eşer I, Khorshid L. Huzurevinde yaşayan yaşılıarda sırt masajının yaşamsal bulgular ve anksiyete düzeyine etkisi. Hacettepe Üniversitesi Hemşirelik Fakültesi Dergisi. 2009;16(2):14-21.

51. Rawtaer I, Mahendran R, Chan HY, Lei F, Kua EH. A nonpharmacological approach to improve sleep quality in older adults. Asia Pac Psychiatry. 2018;10(2):1-5.

52. Ueda T, Suzukamo Y, Sato M, Izumi, S. Effects of music therapy on behavioral and psychological symptoms of dementia: A systematic review and meta-analysis. Ageing Res. Rev. 2013;12:628-41.

53. Sari NLPDY, Rekawati E. The effect of traditional music therapy on blood pressure among elderly with hypertension: a literature review. International Journal of Nursing and Health Services (IJNHS). 2019;2(2):5565.

54. Rubia Orti JE, Pardo MPG, Benllochi M, Drehmer E, Platero JL, Sancho D, Rodriguez MML. Music therapy decreases sadness and Increases happiness in 
alzheimer patients: a pilot study. Neuropsychiatry. 2019:9(1):2013-20.

55. Murabayashi N, Akahoshi T, Ishimine R, Saji N, Takeda $\mathrm{C}$, Nakayama $\mathrm{H}$, et al. Effects of music therapy in frail elderlies: controlled crossover study. Dementia and Geriatric Cognitive Disorders Extra. 2019;9(1):87-99.

56. Jonsson U, Bertilsson G, Allard P, Gyllensvärd H, Söderlund A., Tham A, et al. Psychological treatment of depression in people aged 65 years and over: a systematic review of efficacy, safety, and costeffectiveness. PloS one. 2016;11(8):1-20.

57. Holvast F, Massoudi B, Voshaar RCO, Verhaak PF. Nonpharmacological treatment for depressed older patients in primary care: A systematic review and meta-analysis. PLoS One. 2017;12(9):1-20.

58. Frost R, Bauernfreund $Y$, Walters K. Nonpharmacological interventions for depression/anxiety in older adults with physical comorbidities affecting functioning: systematic review and meta-analysis. Int Psychogeriatr. 2019;31(8):1121-1136. 